\title{
Demokrasi Ekonomi Lokal
}

Oleh:

\section{Mahendra Wijaya}

\begin{abstract}
Abstrak
Artikel ini ingin menunjukkan mengenai sisi demokratis dari usaha bisnis kecil terutama batik di Solo. Dengan menggunakan jaringan sosial berbasiskan kepercayaan dan juga nilai-nilai lokal yang berbasiskan agama dan budaya, usaha bisnis kecil ini dapat bertahan dalam era neoliberal. Semua faktor-faktor ini berhubungan satu sama lain dan menjadi alat utama untuk menciptakan jaminan sosial. Hal ini menunjukkan keterlekatan aktivitas ekonomi dengan konteks sosial budayanya. Berangkat dari realitas tersebut, artikel ini mengusulkan bahwa pemerintah seharusnya memberikan prioritas yang lebih kepada usaha bisnis kecil sebagaimana telah tertulis dalam undang-undang dasar terkait dengan demokrasi ekonomi.
\end{abstract}

Kata kunci: demokrasi ekonomi, usaha kecil lokal, jaringan sosial, keterlekatan

\begin{abstract}
This article wants to show the democratic side of small scale business especially batik in Solo. Using social network based on trust and also local values based on religion and culture, this small scale business can survive in neoliberal era. All of these factors linked each other and become the main tools to create social security. It shows the embededness of economic activity in its social cultural context. From this reality, this article suggest that the state should give more priority to local small scale business, as written in Indonesia's constitution related with economic democracy
\end{abstract}

Keywords: economic democracy, local small bussiness, social network, embeddedness 
Jurnal Pemikiran Sosiologi Volume 1 No.1 , 2012

Mahendra Wijaya

Demokrasi Ekonomi Lokal

\section{Pendahuluan}

Demokrasi ekonomi nasional ber dasarkan pada Undang-Undang Dasar 1945 dan Pancasila. Pasal 33 UUD 1945 menegaskan perekonomian disusun sebagai usaha bersama berdasar atas asas-asas kekeluargaan. Ciri-ciri perekonomian tersebut terumus pada GBHN 1978 yang berisi 8 ciri-ciri positif demokrasi ekonomi. Ciri-ciri positif demokrasi ekonomi antara lain 1) Perekonomian disusun sebagai usaha bersama berdasar atas azasazas kekeluargaan, 2) Cabang-cabang produksi yang penting bagi negara dan menguasai hidup orang banyak dikuasai oleh Negara, 3) Bumi dan air serta kekayaan alam yang terkandung di dalamnya dikuasai oleh Negara dan digunakan untuk sebesarbesarnya kemakmuran rakyat, 4) Sumber- sumber kekayaan dan keuangan Negara digunakan dengan permufakatan Lembaga-lembaga Perwakilan Rakyat, serta pengawasan terhadap kebijaksanaannya ada pada Lembaga Perwakilan Rakyat pula, 5) Warga Negara memiliki kebebasan dalam memilih pekerjaan yang dikehendaki mempunyai hak akan pekerjaan dan penghidupan yang layak, 6) Hak milik perorangan diakui dan pemanfaatannya tidak boleh bertentangan dengan kepentingan masyarakat, 7) Potensi, inisiatif dan daya kreasi setiap warga Negara diperkembangkan sepenuhnya dalam batas- batas yang tidak merugikan kepentingan umum, 8) Fakir miskin dan anak-anak yang terlantar dipelihara oleh Negara. ${ }^{1}$ Disamping ciri-ciri positif disebutkan pula ciri-ciri negatif yang harus dihindari antara lain: 1) Sistem free fight liberalism yang menumbuhkan eksploitasi manusia dan bangsa lain yang dalam sejarahnya di
Indonesia telah menumbuhkan dan mempertahankan kelemahan struktural posisi Indonesian dalam ekonomi dunia, 2) Sistem etatisme dalam mana Negara beserta aparatur ekonomi Negara bersifat dominan serta mendesak dan mematikan potensi dan daya kreasi unit-unit ekonomi di luar sektor Negara, 3) Pemusatan kekuatan ekonomi pada satu kelompok dalam bentuk monopoli yang merugikan masyarakat.

Secara normatif, demokrasi ekonomi menunjuk pada cara produksi dan cara mengelola usaha. Cara produksi disusun berdasarkan usaha bersama, partisipasi, saling menghormati, toleransi terhadap perbedaan dan mengutamakan tujuan bersama. Cara mengelola usaha berdasarkan azas-azas kekeluargaan seperti azas kepercayaan, tolongmenolong dan kerjasama.

Pembahasan sistem demokrasi ekonomi di negaranegara sedang berkembang yang amat penting dibahas adalah sebagai berikut: Pertama, pengertian, sifat-sifat dan pelaksanaan dari demokrasi ekonomi dibentuk, ditentukan dan dilaksanakan oleh masyarakat itu sendiri bukan dari masyarakat lain. Bukan import pengertian kata demokrasi sosialis pada blok timur, kata demokrasi liberal pada blok barat ataupun demokrasi neo liberal dari globalisasi ekonomi. Pengertian, sifatsifat dan pelaksanaan dari demokrasi ekonomi harus bertumpu pada kearifan lokal (local wisdom). Kedua, kesejahteraan bersama (collective gains) menuntut keterlibatan segenap anggota masyarakat untuk memiliki akses terhadap sumber daya produktif guna menghasilkan kebutuhan dasar yang

1 Mubyarto. 1980. Ilmu Ekonomi, Ilmu Sosial dan Keadilan.

Yogyakarta: Yayasan Agro Ekonomika 
memadai bagi diri-sendiri, keluarga, kelompok dan masyarakat. Ketiga, keadilan distribusi (distributional equity) berlangsung melalui hubungan-hubungan produksi dan distribusi. Jaringan produksi dan distribusi bersifat terbuka yang menjamin setiap anggota masyarakat dapat mengambil bagian pekerjaan dan pendapatan. Keempat, sistem perekonomian yang memprioritaskan kepentingan mayoritas anggota masyarakat.

Berdasarkan pokok bahasan di atas pantas dan penting dipertanyakan mengapa sistem perekonomian Indonesia cenderung semakin menjauh dari demokrasi ekonomi? Pada era orde baru mengembangkan politik ekonomi kapitalisme liberal suatu sistem perekonomian digerakkan oleh kekuatan pemilikan modal besar, dorongan untuk memperoleh keuntungan, persaingan bebas dan akumulasi kapital. Ekonomi kapitalisme berbedabeda di satu negara dengan di negara lain, perbedaan tersebut terkait dengan perbedaan sosial budaya politik di masing-masing negara.

Di Indonesia, gaya pemerintahan patrimonial mengkondisikan terciptanya ekonomi kapitalisme buruk, dipenuhi oleh praktek-praktek korupsi, kolusi dan nepotisme. Di bidang perbatikan, kebijakan ekonomi Orde Baru berorientasi pada teknologi tinggi dan padat modal untuk mengejar pertumbuhan ekonomi. Kebijakan ekonomi tersebut mendorong pertumbuhan industri batik printing skala besar. Cara produksi manufaktur batik printing menghasilkan batik printing secara masal, produk halus dan harga murah dibandingkan dengan batik cap. Persaingan tinggi antara batik printing dengan batik cap tidak dapat dihindari, karena kedua jenis produk tersebut ditujukan pada segmen pasar yang sama. Dalam persaingan tersebut, batik printing mempunyai nilai kompetitif yang lebih tinggi dibandingkan dengan produk batik cap. Akibatnya produk batik cap kalah bersaing baik dari segi kualitas maupun harga dan dampaknya tak pelak lagi, sebagian besar pabrikan batik cap di Surakarta terpaksa harus tutup di era tahun 1980an.

Pada akhir 1990-an ekonomi kapitalisme liberal semakin tidak terkendali menyimpang jauh dari ekonomi kapiatalisme yang demokratis. Ekonomi kapitalime liberal semakin liar bersamaan dengan globalisasi ekonomi. Lembaga ekonomi internasional seperti World Trade Organization (WTO), International Monetary Fund (IMF) dan World Bank mengembangkan sistem pasar bebas dengan cara menghapus sekat-sekat ekonomi negara-negara di dunia. Ekonomi kapitalisme menciptakan kebebasan baru (neoliberal) melalui lembaga ekonomi internasional. Transnational Corporation (TNC) membimbing, mengarahkan dan mengembangkan kapitalisme neo liberal sebagai kekuatan pasar yang tidak terkendali. Globalisasi pasar bergerak dengan modus privatisasi, ekspansionis dan predatory.

Transnational Corporation (TNC) memiliki modal sangat besar, misalnya pada tahun 2002 Wal Mart memiliki asset ekonomi sebanyak 217,89 billion USD, sementara asset ekonomi Indonesia pada tahun 2002 hanya 145 billion USD. Dalam kaitannya dengan industri batik, TNC dengan mudah mendominasi industri dan perdagangan bahan baku seperti benang, kain dan zat kimia pewarna. Globalisasi pasar bermakna ganda di satu sisi sangat 
menguntungkan bagi TNC di negara -negara industrial dan di sisi lain mematikan (predatory) ${ }^{2}$ perusahaan-perusahaan domestik di negara berkembang. Pada awal abad ke 21, industri benang dan kain rayon lokal banyak yang gulung tikar akibat dipermainkan dan kalah bersaing dengan produk benang dan kain rayon dari TNC di bidang pertekstilan Cina.

Sistem perekonomian kapitalisme neoliberal beroperasi seperti kuda liar yang tidak menentu sepak terjangnya. Gagal membangun ekonomi kapitalisme yang bersifat demokratis, seperti kuda pacu berlari kencang pada jalurnya. Ekonomi kapitalisme neoliberal mendesak ruang gerak ekonomi lokal dan menimbulkan masalah kemiskinan struktural yang berkepanjangan. Pembangunan demokrasi ekonomi yang diorganisir oleh masyarakat pusat atau golongan elite menghasilkan jalan buntu bahkan menyimpang jauh dari cita-cita bangsa Indonesia.

Pembangunan demokrasi ekonomi nasional memang seharusnya berakar dari ekonomi lokal bukan terpusat dari golongan elit. Pada ekonomi lokal, kelompok-kelompok sosial ekonomi mempunyai perasaan sebagai satu komunitas. Masalah ekonomi harus diselesaikan secara bersama melalui pertukaran ekonomi yang adil. Ekonomi komunitas memiliki karakteristik sosial budaya yang beragam, berbeda antara satu komunitas dengan komunitas lainnya. Seperti sosial budaya komunitas petani padi sawah berbeda dengan komunitas nelayan dan komunitas pengrajin pembatik. Kampung batik Laweyan memiliki

\footnotetext{
2 lihat Gelinas, Jaques B. 2003. Juggernaut Politics. Understanding Predatory Globalization. London \& New York: Zed Books. Hal 5677
}

karakteristik sosial ekonomi unik dan spesifik berbeda dengan pada umumnya karakteristik sosial budaya masyarakat kota Solo. Ekonomi kampung batik laweyan terbukti dapat bertahan dari berbagai tekanan politik ekonomi dari zaman ke zaman. Ketahanan ekonomi kampung batik Laweyan terkait dengan basis nilai-nilai budaya, ilmu pengetahuan dan teknologi, inisiatif dan kreativitas serta organisasi ekonomi lokal.

\section{B. Ekonomi Lokal Kampung Batik Laweyan ${ }^{3}$}

Asal usul batik tulis Jawa, baik dari segi corak maupun sisi komersialnya tidak dapat dipisahkan dari sejarah Kerajaan Mataraman. Desa Laweyan merupakan desa kuno yang sudah ada sebelum berdirinya kerajaan Pajang. Penduduk desa Laweyan hanyalah masyarakat kecil atau biasa disebut wong lumrah, tidak banyak meninggalkan situs sejarah yang berarti. Desa Laweyan baru dianggap berarti setelah dikaitkan dengan keberadaan situs sejarah Ki Ageng Anis seorang pejabat negara kadipaten Pajang yang bertempat tinggal di Laweyan pada tahun 1546 Masehi. Disamping itu Ki Ageng Anis juga dikenal sebagai tokoh agama syiar Islam dan empu kerajinan batik. Islam dan kerajinan batik tidak dapat dipisahkan. Pada masa itu, kerajinan batik tulis merupakan hasil karya seni yang mulai ditekuni oleh masyarakat di sekitar sungai Kabanaran. Desa Laweyan menjadi bandar dari prau-prau yang hilir mudik memuat barang dagangan di sepanjang aliran sungai

\footnotetext{
${ }^{3}$ Wijaya, Mahendra. 2008. Ekonomi Komersial Ganda: Perkembangan Kompleksitas Jaringan Sosial Ekonomi Perbatikan Di Surakarta. Disertasi S3 Pascasarjana UGM.
} 
Kabanaran. Pada saat itu sungai Kabanaran menyediakan air berlimpah dan sangat memungkinkan daerah tersebut dijadikan sebagai tempat penjemuran, pencucian dan bandar batik yang ramai. Potensi lingkungan mendukung usaha batik tulis cepat berkembang di tepi sungai Kabanaran. Desa Laweyan kuno yang dikenal menghasilkan kain batik tulis dengan corak batik tulis geometrisan Jawa Mataraman. ${ }^{4}$

Sedangkan keberadaan batik tulis dengan corak atau pola batik Surakarta berasal dari Keraton Kasunanan Surakarta. Pakoe Boewono III membuat busana dengan gaya batik Surakarta baik pola, warna maupun makna pemakaiannya. Pada abad ke19 kerajaan Kasusunan Surakarta mengalami pertumbuhan ekonomi sehingga menimbulkan kebutuhan penduduk akan kain batik tulis meningkat. Pada saat itu masyarakat Surakarta mengenal produk batik halus (batik tulis) dan batik kasar atau batik saudagaran (batik cap) yang ditujukan pada segmen pasar yang berbeda ${ }^{5}$ Batik halus diproduksi oleh kerabat abdi dalem karaton Kasunanan Surakarta dan batik saudagaran diproduksi di kampung batik Laweyan.

\section{Sarekat Dagang Islam}

Kejayaan produsen dan pedagang batik terkait dengan keberadaan Sarekat Dagang Islam yang didirikan oleh H. Samanhudi dan tokoh lainnya pada tahun 1912 di Laweyan Solo. Sarekat Dagang Islam

\footnotetext{
4 Sejarah Kampung Laweyan lihat Priyatmono, Alfa Febela. 2000. Studi Kecenderungan Perubahan Morfologi Kawasan Di Kampung Laweyan Surakarta. Program Pascasarjana Universitas Gadjah Mada Yogyakarta.

${ }^{5} \mathrm{H}$ Santosa Doellah mengemukakan batik tulis merupakan proses sehelai wastra yakni sehelai kain yang dibuat secara tradisional dan terutama juga digunakan dalam matra tradisional beragam hias
}

kemudian berganti nama Sarekat Islam dengan tujuan Pertama,memajukan perdagangan. Kedua, memberikan pertolongan kepada para anggota yang mendapat kesukaran Ketiga, memajukan kepentingan jasmani dan rokhani kaum bumiputera. Keempat, memajukan kehidupan agama Islam. Kelima, menyusun masyarakat Islam, agar bisa hidup berkumpul menjadi saudara. Keenam, menggerakkan hati umat Islam supaya bersatu dan bertolong-tolongan. Ketujuh, di dalam lingkungan dan batas undang-undang negara, melakukan segala daya upaya kesentausaan dan tumpah darahnya. Hal ini dapat dimaknai bahwa keberadaan Sarekat Dagang Islam di ekonomi kampung batik Laweyan berorientasi pada ekonomi produktif, egaliter, saling menghormati, kebersamaan, toleransi dan tolongmenolong.

Anggota Syarekat Islam berkembang dengan cepat dan meluas sampai ke pelosok Jawa dan luar Jawa. Pada tahun 1913 anggota Sarekat Islam sebanyak 80.000 orang meningkat pada tahun 1918 menjadi 450.000 orang dari 87 anak cabang yang tersebar di Hindia Belanda. Keberadaan Sarekat Islam dengan cepat meningkatkan jaringan perdagangan batik pribumi Surakarta sampai kepelosok wilayah Hindia Belanda.

Pemerintah kolonialis Belanda menjadi sangat khawatir akan kekuatan sosial ekonomi penduduk pribumi muslim, maka ia melakukan serangkaian tekanan politik ekonomi terhadap keberadaan

pola batik tertentu yang pembuatannya menggunakan teknik celup rintang dengan malam lilin batik sebagai bahan perintang warna. Kerajinan batik tulis menggunakan teknologi tradisional , ketelitian kerja, tahap produksi yang panjang, waktu produksi lama dan produktivitas kerja rendah dalam Batik Pengaruh Zaman dan Lingkungan. Penerbit Danarhadi Surakarta.2002.hal:10. 
Sarekat Dagang Islam.Tekanan politik ekonomi secara terus-menerus akhirnya membuat Sarekat Dagang Islam menjadi lemah dan mengakibatkan kemunduran jaringan perdagangan batik pribumi. ${ }^{6}$

Pedagang perantara bahan baku batik keturunan Tionghoa memiliki modal dan solidaritas kuat memanfaatkan kemunduran usaha batik pribumi. Mereka ekspansi ke dalam usaha produksi batik dengan corak dan warna batik khas Cina, seperti merah dan biru. Mereka mengembangkan mode produksi putting out, yaitu hubungan antara pedagang bahan baku batik keturunanTionghoa dengan pengrajin pembatik atau pekerja rumahan di pedesaan. Sejak saat itu terjadi persaingan tinggi antara pengusaha batik pribumi dengan pedagang batik keturunan Tionghoa dalam produksi dan perdagangan batik di Surakarta.

Tekanan politik ekonomi kolonialisme Belanda dan persaingan bisnis dengan pedagang batik keturunan Tionghoa menimbulkan industri rumah tangga batik tulis dan pabrikan batik cap yang mandiri terfragmentasi kedalam unit-unit usaha mbatik, mbironi, medel dan babaran. Mode produksi industri rumah tangga tidak mandiri lagi di suatu tempat, melainkan proses produksi terpecah-pecah kedalam unit-unit usaha yang terspesialisasi. Kondisi tersebut dan kekuatan modal sosial menumbuhkan hubungan produksi nempakke yaitu jaringan hubungan produksi antar unit-unit usaha spesialisasi. Hubungan produksi nempakke terbentuk dari hubungan saling percaya, timbal-

\footnotetext{
${ }^{6}$ George D. Larson mengungkapkan kolonialisme Hindia Belanda memotong dukungan Kraton Kasunanan Surakarta terhadap Sarekat Islam dalam Masa Menjelang Revolusi Kraton dan
}

balik dan kerja sama. Hubungan produksi nempakke terus bertahan hingga sekarang ini.

\section{Ethos Kerja Santri}

Kampung batik Laweyan di Surakarta berkembang sebagai kampung santri yang taat menjalankan ibadah Agama Islam. Hal itu terkait dengan keberadaan Kyai Ageng Anis pada akhir abad ke 16 di Laweyan. Ajaran ulama besar Islam tersebut secara turun-temurun menjiwai dunia kehidupan para santri di kampung batik tersebut. Arti dan makna kerja sebagai ibadah dan sillahturohmi mendatangkan barokah telah mengakar kedalam kehidupan sosial ekonomi para santri. Keberadaan batik tidak hanya sebagai simbol seni budaya Jawa namun juga sebagai simbol kesejahteraan santri dan kemakmuran masjid. Hal itu mendukung terpeliharanya hubungan saling percaya, normanorma resiprositas dan kerja sama dalam hubunganhubungan produksi dan hubungan-hubungan dagang.

Dalam perkembangannya pengusaha dan pengusaha muslim di kampunng batik Laweyan terbagi menjadi dua kelompok, yaitu kelompok Muhamadiyah di bagian barat Laweyan dan kelompok Nahdatul Ulama di bagian timur Laweyan. Kedua kelompok sosial keagamaan Islam tersebut sebagai wadah pengusaha dan pengusaha batik di Laweyan. Kedua lembaga keagamaan tersebut memiliki kelompok-kelomok majelis taklim untuk mengembangkan kegiatan peribadatan Islam sesuai dengan aliran mereka masing- masing. Majelis

Kehidupan Politik di Surakarta 1912-1942. Gadjah Mada University Press. Hal :72-76. 
taklim dimanfaatkan juga oleh para anggotanya sebagai wadah saling berbagi informasi bisnis, seperti informasi harga, barang dagangan, transportasi, modal dan pasar bahkan dalam batasbatas tertentu sebagai wadah saling berbagi order pekerjaan dan saling pinjam-meminjam modal usaha. Kepercayaan, hubungan timbal-balik dan jaringan kerja sama di dalam kelompok-kelompok majelis taklim tersebut menunjang kegiatan ekonomi pengusaha dan pengusaha batik di Laweyan.

Pada kelompok Muhammadiyah terjadi perubahan ideologis terjadi karena munculnya generasi baru yang lebih terpelajar tapi mempunyai perhatian terhadap masalah-masalah sosial keagamaan. Mereka menafsirkan agama dengan dibantu oleh ilmu pengetahuan umum untuk memahami masalah-masalah sosial ekonomi yang dihadapi umat serta menemukan jawaban-jawaban praktisnya. Oleh karena itu perubahan kehidupan beragama memberi imbas bagi perubahan etos kerja. Ajaran yang menganjurkan agar seorang Muslim melakukan yang terbaik untuk kepentingan dunianya seolah dia akan hidup selamanya. Melakukan hal yang sama untuk kehidupan akheratnya seolah dia akan mati keesokan harinya. Dalam interpretasi barunya itu, kalangan Muhammadiyah menganjurkan perlunya keseimbangan antara penekanan terhadap pentingnya kehidupan relegius yang bisa dijadikan bekal bagi kehidupan setelah mati dan tidak ditinggalkan masalah dunia karena hal itu akan memberi kontribusi bagi dilaksanakannya kehidupan relegius. Interpretasi ini menumbuhkan dorongan rasional ekonomi dalam mengembangkan usaha batik. Aktivitas usaha batik dikembangkan melalui perencanaan dan persiapan kedepan yang lebih baik

Pada kelompok Nahdatul Ulama terjadi perubahan pemaknaan yang berhubungan dengan masalah dunia dan akhirat. Kehidupan akherat tidak terlepas dari masalah duniawi, karena praktek-praktek peribadatan memerlukan dukungan faktor duniawi. Doa umum yang sering dipanjatkan oleh setiap santri "Robbana Atina Fidduniaaaa hasanah wafil akhirati hasanah waqina azabannar" Ya allah berilah kami kebaikan di dunia dan di akherat nanti, dan jauhkanlah kami dari api neraka. Meminta kebaikan di dunia dan akherat nanti menunjukkan bahwa pada dasarnya kehidupan akherat memiliki moralitas nilai yang sama dengan kehidupan di dunia. Interprestasi baru ini menumbuhkan dorongan moral ekonomi dalam mengembangkan usaha batik. Pengusaha dan pengusaha batik membangun kepercayaan, hubungan timbal-balik dan jaringan sosial ekonomi perbatikan dalam mengembangkan usaha.

Pengalaman pahit akibat persaingan bisnis antara batik printing dengan batik cap yang tidak berimbang mengakibatkan batik cap kalah bersaing dan sebagian tutup usaha. Pengalaman pahit berikutnya sengitnya persaingan bisnis di era globalisasi pasar. Hubungan ekonomi internasional makin terbuka karena kepentingan pelaku ekonomi suatu negara untuk meningkatkan produksi dan distribusi makin saling tergantung dengan pelaku ekonomi negara lain. Oleh sebab itu permasalahan ekonomi lokal bukanlah semata-maka akibat dari kondisi ekonomi domestik, tetapi juga merupakan konsekuensi dari adanya saling ketergantungan antar pelaku ekonomi negara dengan negara lain. 
Jurnal Pemikiran Sosiologi Volume 1 No.1 , 2012

Mahendra Wijaya

Demokrasi Ekonomi Lokal

Peningkatan ekspor akan produk batik mendatangkan keuntungan bagi produsen pedagang batik lokal. Akan tetapi juga dapat menimbulkan masalah bagi produsen-pedagang batik lokal. Permasalahan ekonomi tersebut bersumber dari ketidaksiapan produsen-pedagang batik lokal dalam mempersiapkan. Hak Atas Kekayaan Intelektual (HAKI) atas kreasi batiknya. Buyer luar negeri memanfaatkan ketidaksiapan tersebut untuk mengambil alih hak merk produk batik buatan kampung batik Laweyan Surakarta. Pengalaman dalam dunia bisnis tersebut menimbulkan perubahan pemaknaan terhadap persaingan bisnis.

Perubahan pemaknaan terhadap ideologi dan persaingan bisnis menimbulkan revitalisasi ethos kerja Mbok Mase yaitu bekerja dengan ulet dan gigih yang berarti kerja keras, rajin,disiplin, juga terkenal gemi setiti lan ngati-ngati artinya teliti, hemat, dan menabung. ${ }^{7}$ Mbok Mase menghormati dan menjalankan ungkapan wong temen iku tinemu artinya orang yang rajin dan tekun bekerja akan menemukan kebahagiaan. Setiap hari Mbok Mase bekerja sekitar 12 jam baik di dalam perusahaan maupun di pasar. Mbok Mase dibantu Mas Nganten menjalankan serangkaian kegiatan usaha dari menentukan bahan baku kain, menentukan corak batik, membagi tugas kepada para tukang dan buruh , meramu zat pewarna , pengepakkan kain, sampai dengan berdagang di pasar. Mbok Mase terkenal sebagai orang yang tak mau kompromi dengan siapapun, seperti dengan teman, tetangga, kerabat, bahkan dengan anaknya sendiri dalam rangka

\footnotetext{
7 Soedarmono.1987.Munculnya Kelompok Pengusaha Batik di Laweyan Pada Awal Abad XX.Fakultas Pasca Sarjana Universitas Gadjah Mada.
}

menegakkan disiplin kerja. Ia dikenal sangat menghargai waktu dalam kehidupan sehari-harinya, membagi waktu untuk kepentingan ibadah, bekerja, keluarga ,dan kegiatan sosial. Ia juga teliti dalam mengendalikan kualitas produksi untuk menjaga mutu produk batik untuk memuaskan pelanggan. Rajin mencatat barang dan uang yang masuk dan keluar setiap harinya. Hemat dalam mengeluarkan uang, setiap mengeluarkan uang selalu diperhitungkan agar tidak mengganggu pengembangan usahanya. Pengusaha Mbok Mase tergolong orang yang suka membangun rumah besar yang dikelilingi tembok tinggi sekitar 3-4 meter. Mengembangkan tata ruang rumah lengkap dengan ruang keluarga, ibadah, produksi dan showroom.

Pengusaha dan pengusaha batik mempunyai kesadaran baru akan pentingnya persaingan dalam bisnis. Memiliki keberanian untuk bersaing dalam bisnis dengan cara sportif. Keberanian tidak sekedar emosional melainkan keberanian yang telah dipikirkan, dirancang dan disiapkan dengan baik. Kesadaran pentingnya mengejar prestasi untuk memenangkan persaingan bisnis. Kreativitas dan inovatif menciptakan pola batik, pewarnaan dan desain pakaian sesuai dengan perkembangan zaman. Munculnya kesadaran akan pentingnya citra "merk" produk batik buatan lokal sebagai produk unggulan dalam persaingan bisnis pengusaha, dan pengusaha memiliki kesadaran akan pentingya waktu dalam persaingan bisnis. Memanfaatkan waktu sebaik mungkin untuk mempersiapkan atau merencakan usaha ke masa depan yang lebih baik. 
Pengusaha batik semakin terbuka bagi kritik dan saran membangun dari para stakeholder melalui acara bulanan Selaweyan dengan media sarasehan, pertunjukan seni, pasar murah kepada masyarakat umum baik dari dalam negeri maupun turis luar negeri.

\section{Unit Usaha Berbasis Keluarga Besar}

Unit usaha batik berbasis dan dikelola oleh keluarga besar. Struktur keluarga besar terdiri dari Mbok Masse sepuh-Mas Nganten sepuh dan Mbok Mase-Mas Nganten serta Den Bagus -Den Rara adalah serangkain kakek- nenek, bapak - ibu dan anak perempuan-anak laki-laki yang gigih dan ulet mengelola usaha batik. Keluarga besar mendukung dan mempercayakan Mbok Mase untuk mengembangkan usaha batik. Pengusaha batik Mbok Mase di kampung batik Laweyan Surakarta mengembangkan jaringan kelompok usaha induksemang berdasarkan ikatan kekerabatan menurut garis keturunan laki-laki. Jaringan hubungan induk (orang tua) dan semang (anak) berdasarkan hubungan saling percaya, hubungan saling tolongmenolong dan hubungan kerja sama di bidang usaha perbatikan. Jaringan kelompok induk semang sebagai saluran kerja sama bisnis,seperti saling memberikan informasi pasar, saling pinjam meminjam barangan dagangan, modal uang tunai dan saling pinjam-meminjam sarana transportasi serta saling memberi order pekerjaan.

Pengusaha batik membentuk modal ekonomi, sosial dan budaya berbasis keluarga besar. Modal ekonomi terdiri dari tempat usaha, peralatan produksi, modal uang tunai, bahan baku, barang dagangan, alat komunikasi dan sarana transportasi. Modal sosial terdiri dari kepercayaan, norma tolong-menolong dan jaringan sosial. Modal budaya terdiri dari pengetahuan, teknologi dan ketrampilan mengelola usaha. Modal sosial budaya ekonomi cenderung semakin besar karena terakumulasi secara turun temurun. Akumulasi modal ekonomi sosial budaya merupakan sumberdaya produktif yang membimbing, mengarahkan dan mengembangkan industri dan perdagangan batik.

\section{Partisipasi dan Kebersamaan Pengusaha} Batik.

Belajar dari pengalaman pahit runtuhnya industri batik cap skala kecil akibat kalah bersaing dengan industri batik printing skala besar, tumbuhlah kesadaran akan pentingnya kebersamaan usaha dalam komunitas. Pengusaha batik mengutamakan kepentingan bersama dari pada kepentingan perseorangan. Seperti dalam ungkapan pengusaha batik tuna sathak bani sanak, laba sedikit tidak apaapa asalkan banyak saudara. Hal itu terbentuk berkaitan dengan kepadatan tali pengikat di antara pengusaha batik seperti ikatan keagamaan, ikatan persaudaraan dan ikatan ketetanggaan membentuk kebersamaan usaha. Pedoman hidup dalam hubungan-hubungan sosial sebagaimana ungkapan Ojo dumeh, sebagai peringatan agar setiap orang selalu ingat sesamanya. Ojo dumeh sugih, tumindake lali karo wong ringkih artinya janganlah mentangmentang kaya, lalu perbuatannya tidak mengingat mereka yang lemah ekonomi. Ojo dumeh kuwasa, tumindake daksura lan daksia marang sepadha-padha, artinya janganlah mentang mentang berkuasa sehingga tindak tanduknya sombong dan sewenang-wenang terhadap sesamanya. Ojo dumeh 
menang tumindake sewenang- wenang, artinya janganlah mentang-mentang telah dapat mengalahkan lawan, lalu tindakannya sewenangwenang terhadap yang dikalahkan. Ojo dumeh pinter tumindake keblinger, artinya jangan mentang-mentang pintar, lalu tindakannya menyimpang dari aturan-aturan yang seharusnya. Ojo dumeh kuat lan gagah, tumindake sarwo gegabah, artinya jangan mentang-mentang kuat dan gagah, lalu tindakannya semaunya sendiri. Pengusaha batik mengutamakan kepentingan bersama dari pada kepentingan orang per-orang dalam usaha batik. Mendahulukan keselamatan bersama dari pada risiko yang dapat mengancam dirinya sendiri. Seperti ikatan sapu lidi, satu per satu lidi sangat mudah dipatahkan akan tetapi ikatan puluhan/ratusan lidi tidak dapat dipatahkan oleh kekuatan apapun. Kesadaran sosial ekonomi itulah mendorong partisipasi pengusaha batik membangun Paguyuban Kampung Batik Laweyan pada tahun 2004. Paguyuban tersebut kemudian berganti nama Forum Kampung Batik Laweyan. Keberadaan Forum Kampung Batik Laweyan membangkitan kembali dinamika usaha batik. Forum Kampung Batik Laweyan berfungsi sebagai saluran partisipasi pengusaha batik dalam sosialisasi budaya batik, mengembangkan ketrampilam tenaga kerja, meningkatkan teknologi informasi dan komunikasi bisnis, memantapkan teknologi produksi dan memajukan pemasaran bersama.

\section{Koperasi Batik}

Pada masa kemerdekaan Republik Indonesia, pemerintahan orde lama mengeluarkan kebijakan program benteng yang bertujuan untuk menumbuhkan kewiraswastaan pribumi. Dalam bidang perbatikan, pemerintah mendirikan koperasi sekunder Gabungan Koperasi Batik Indonesia (GKBI) yang anggotanya terdiri dari koperasi primer di daerah-daerah. Sejak tahun 1950 GKBI memiliki lesensi monopoli impor bahan baku. Oleh sebab itu, GKBI berhasil membantu pengadaan bahan baku mori, obat-obatan dan pemasaran batik sekitar 10 hingga 15 persen dari hasil produksi para anggotaanggotanya. Program benteng secara umum dianggap distorsi dan gagal menumbuhkan wiraswasta pribumi di Indonesia, namun di bidang perbatikan program tersebut menimbulkan efek positif,.yaitu pemupukan modal, penyerapan tenaga kerja, peningkatan keterampilan kerja, dan meluasnya industri batik tulis dan cap di berbagai penjuru Kota Surakarta. Pada tahun 1960-an Pasar Klewer mulai berkembang menjadi pasar pedagang batik tulis dan cap. Jaringan perdagangan batik meluas dari sentra-sentra produksi batik di Surakarta dan sekitarnya sampai ke pasar domestik. Program benteng dalam bidang perbatikan di Surakarta berhasil menumbuhkan pabrikan batik cap/ industri rumah tangga batik tulis. Pabrikan batik cap dan industri rumah tangga batik tulis dengan cepat menyebar ke seluruh penjuru Kota Surakarta dan sekitarnya,seperti Kauman, Laweyan Semanggi, Sangkrah, Kedunglumbu Pasar Kliwon Surakarta, Bayat Klaten, Masaran Sragen ,dan Bekonang Sukoharjo. 


\section{Hubungan Kerja Kemanusiaan: Ngenger}

Ungkapan sapa gawe nganggo, sapa nandur ngunduh artinya siapa membuat akan memakai dan siapa menanam akan memetik. Setiap perbuatan yang baik tentu akan menghasilkan kebaikan. Ungkapan ini melandasi berkembangnya hubungan kerja ngenger, pengusaha batik memaknai hubungan dengan buruh batik seperti hubungan orang tua dengan anak. Pengusaha batik merasa memiliki tanggung jawab moral untuk memberi kesejahteraan dan ketrampilan bagi masa depan anak asuhnya. Hubungan kerja ngenger berfungsi mentransfer ilmu pengetahuan, ketrampilan membatik dan mengelola pabrikan. Sistem ngenger memungkinkan terjadinya proses mobilitas vertikal ke atas dari buruh batik menjadi pengusaha batik. Pengusaha batik dengan tulus memberi pengetahuan dan ketrampilan membatik kepada buruh ngenger, sehingga buruh ngenger tersebut lambat laun berhasil menjadi pengrajin pembatik. Pengrajin pembatik yang gigih dan ulet belajar membatik membatik dari majikannya, sehingga pengrajin pembatik tersebut suatu saat mampu berkreasi menciptakan pola batik. Kualitas pengrajin pembatik terus berkembang menjadi seorang pengrajin pembatik spesialisasi ahli dalam membuat pola batik. Pengrajin pembatik spesialisasi tersebut sedikit-demi sedikit menabung untuk bekal masa depan. Berbekal pengetahuan, ketrampilan, sikap kerja dan hasil tabungan maka pengrajin pembatik spesialisasi tersebut merintis usaha sendiri, atau industri rumah tangga batik tulis mandiri di desa asalnya. Pengrajin pembatik mandiri memanfaatkan keterikatan historis dengan mantan pengusaha batiknya untuk menjalin hubungan kerja sub kontrak industrial.

\section{Jaringan Sosial Ekonomi Perbatikan Berbasis Kepercayaan.}

Perkembangan teknologi perbatikan menciptakan peningkatan mode produksi batik dan pada gilirannya menumbuhkan kompleksitas jaringan sosial ekonomi. Peningkatan mode produksi batik yang berlangsung di kampung batik Laweyan adalah sebagai berikut:

1) Mode produksi industri rumah tangga batik tulis di kelola oleh pengrajin pembatik dibantu oleh tenaga kerja keluarga tanpa upahan dan beberapa tenaga kerja upahan dari luar keluarga. Keseluruhan kegiatan dilaksanakan secara manual dibantu oleh teknologi produksi lokal seperti canting, gawangan, anglo, kipas angin dan lain-lain. Proses produksi berlangsung panjang, lama. dan menghasilkan produk batik tulis secara bijian.

2) Mode produksi pabrikan batik cap sangat berbeda dari mode produksi industri rumah tangga batik tulis. Para pekerja tidak lagi bekerja di rumahnya masing-masing, tetapi pekerja datang ke pabrik untuk menyelesaikan serangkaian tugas di bawah satu atap. Teknologi canting diganti dengan teknologi cap atau stempel, sehingga proses produksi batik cap lebih cepat dari pada proses produksi batik tulis. Demikian pula hasil produk batik dari pabrikan batik cap lebih banyak dari pada industri rumah tangga batik tulis.

3) Mode produksi manufaktur batik printing hampir sama dengan mode produksi pabrikan, tetapi 
Jurnal Pemikiran Sosiologi Volume 1 No.1 , 2012

Mahendra Wijaya

Demokrasi Ekonomi Lokal

berbeda dalam tingkat teknologi yang digunakan.

Dalam bentuk pabrikan, rangkaian pekerjaan diselesaikan oleh pekerja secara manual. Tetapi dalam mode produksi manufaktur, rangkaian pekerjaan dominan diselesaikan oleh mesin : printing sablon dan printing mesin import untuk menghasilkan produk massal

4) Mode produksi campuran, yaitu mode produksi manufaktur batik printing tulis, pabrikan batik cap tulis. Mode produksi ini menggabungkan teknologi lokal-impor dalam proses produksi pembuatan batik Mode produksi campuran ini menumbuhkan keterkaitan vertikal dan antar ruangan antara industri rumah tangga batik tulis pada sektor ekonomi tradisional dengan pabrikan batik cap tulis dan manufaktur batik printing tulis pada sektor ekonomi modern

Peningkatan mode produksi menumbuhkan kompleksitas jaringan sosial ekonomi sebagai berikut: 
Jurnal Pemikiran Sosiologi Volume 1 No.1 , 2012

Mahendra Wijaya

Demokrasi Ekonomi Lokal

\section{Bagan 1.1}

\section{Jaringan Sosial Ekonomi Perbatikan}

\begin{tabular}{|c|c|c|c|}
\hline No & $\begin{array}{c}\text { Tipe Jaringan } \\
\text { Hubungan Produksi }\end{array}$ & $\begin{array}{c}\text { Unit-unit usaha/tipe } \\
\text { pelaku yang terkait }\end{array}$ & Pola Hubungan Kerja \\
\hline a. & $\begin{array}{c}\text { Jaringan hubungan } \\
\text { sub kontrak } \\
\text { industrial spsialisasi }\end{array}$ & $\begin{array}{c}\text { Antara industri rumah } \\
\text { tangga dengan industri } \\
\text { besar }\end{array}$ & $\begin{array}{c}\text { Pola hubungan produksi } \\
\text { kerja sama saling } \\
\text { menguntungkan }\end{array}$ \\
\hline b. & $\begin{array}{c}\text { Jaringan hubungan } \\
\text { produksi nempakke }\end{array}$ & $\begin{array}{c}\text { Pengusaha pemroses, } \\
\text { mandor penggarap dan } \\
\text { pengrajin pembatik }\end{array}$ & $\begin{array}{c}\text { Pola hubungan produksi } \\
\text { kerja sama saling } \\
\text { menguntungkan }\end{array}$ \\
\hline c. & $\begin{array}{c}\text { Jaringan hubungan } \\
\text { dagang ngalap nyaur }\end{array}$ & $\begin{array}{c}\text { Pengusaha dengan } \\
\text { pengusaha batik di dalam } \\
\text { dan di luar Pasar Klewer }\end{array}$ & $\begin{array}{c}\text { Pola hubungan dagang } \\
\text { kerja sama saling } \\
\text { menguntungkan }\end{array}$ \\
\hline d. & $\begin{array}{c}\text { Jaringan hubungan } \\
\text { dagang induk semang }\end{array}$ & $\begin{array}{c}\text { Pedagang induk dan } \\
\text { pedagang semang (orang } \\
\text { tua dan anak) }\end{array}$ & $\begin{array}{c}\text { Pola hubungan dagang } \\
\text { kerja sama saling } \\
\text { menguntungkan }\end{array}$ \\
\hline e. & $\begin{array}{c}\text { Jaringan hubungan } \\
\text { dagang dengan } \\
\text { sistem koodinator } \\
\text { wilayah }\end{array}$ & $\begin{array}{c}\text { Pengusaha batik dari } \\
\text { kampung batik Laweyan } \\
\text { dengan pengusaha batik } \\
\text { luar kota }\end{array}$ & $\begin{array}{c}\text { Pola hubungan dagang } \\
\text { kerja sama saling } \\
\text { menguntungkan }\end{array}$ \\
\hline f. & $\begin{array}{c}\text { Jaringan hubungan } \\
\text { sub kontrak } \\
\text { komersial domestic }\end{array}$ & $\begin{array}{c}\text { Pengusaha batik dari } \\
\text { kampung batik Laweyan } \\
\text { dengan pengusaha batik } \\
\text { luar kota }\end{array}$ & $\begin{array}{c}\text { Pola hubungan dagang } \\
\text { kerja sama saling } \\
\text { menguntungkan }\end{array}$ \\
komersial eksport & $\begin{array}{c}\text { Perusahaan batik lokal } \\
\text { dengan perusahaan } \\
\text { dagang luar negeri. }\end{array}$ & $\begin{array}{c}\text { Pola hubungan dagang } \\
\text { kerja sama saling } \\
\text { menguntungkan }\end{array}$ \\
\hline
\end{tabular}


Ada kecenderungan pola jaringan hubungan sosial ekonomi perbatikan bersifat hubungan kerja sama yang saling menguntungkan. Hal itu berkaitan dengan sikap pengusaha batik terhadap pengusaha batik lainnya yang dilandasi oleh kepercayaan dan tepa selira (toleransi) yang berarti bahwa apabila kita merasa senang dan bahagia jika orang lain berperilaku baik terhadap kita, maka kita hendaknya juga berusaha berperilaku baik terhadap orang lain. Nilai sosial inilah yang melandasi terbangunnya jaringan hubungan sosial ekonomi perbatikan. Kompleksitas jaringan sosial ekonomi yang berbasis pada hubungan saling kepercayaan, hubungan saling menguntungkan (reciprocity) dan kerja sama.

\section{Strategi Rasional Pengusaha Batik}

Strategi rasional merupakan pola-pola berbagai usaha yang direncanakan oleh pengusaha batik untuk dapat memenuhi syarat minimal yang dibutuhkan dalam memecahkan masalah yang dihadapi dalam produksi dan perdagangan batik. Dimensi rasional dari tindakan-tindakan ekonomi pengusaha batik tampak pada aktivitas produksi dan perdagangan yang ditujukan untuk memperoleh keuntungan bagi diri sendiri dan lingkungannya. Keuntungan bagi lingkungan berdasarkan pertimbangan nilai kebersamaan, kepercayaan dan timbal balik.

\section{(1). Strategi Rasional Dalam Produksi}

Pada akhir tahun 2006. harga bahan baku kain batik ATM (Alat Tenun Mesin) rayon untuk terus meningkat. Kenaikan kain rayon tersebut bersumber dari kenaikan harga serat rayon di pasaran internasional. Perusahaan serat rayon lokal meraup keuntungan besar dari perdagangan ekspor serat rayon ke negeri Cina. Di negeri Cina serat rayon tersebut

digunakan sebagai bahan baku pembuatan produk kertas dan pampers. Oleh sebab itu persediaan serat rayon di Indonesia makin terbatas, sehingga harga serat rayon meningkat. Kenaikan serat rayon diikuti oleh kenaikan harga benang rayon dan kain rayon. Harga kain rayon meningkat dari harga Rp 15 000,per meter pada akhir tahun 2006 menjadi Rp20.000,- per meter pada akhir tahun 2006 atau naik 33,33 persen. Demikian pula kain ATBM (alat tenun bukan mesin) primisima pada awal tahun 2006 seharga $\mathrm{Rp} 20.000$,- per meter menjadi $\mathrm{Rp}$ 30.000 ,- per potong atau naik 33,33 persen. Kenaikan bahan baku kain ATM rayon dan ATBM primisima menimbulkan kenaikan biaya produksi batik dan harga kain. Demikian pula pakaian batik ikut meningkat harganya mencapai 30 persen. Kenaikan harga bahan baku kain batik dan produk batik cap printing menyebabkan daya beli masyarakat dan permintaan domestik akan produk batik ikut menurun.

Kondisi ekonomi tersebut mendorong pengusaha batik memilih strategi rasional mengembangkan produksi berorientasi ekspor. Pengusaha memanfaatkan teknologi informasi dan komunikasi internet sebagai media promosi kedalam pasar global. Jaringan relasional pemasaran batik semakin bertambah dari waktu ke waktu disertai kenaikan permintaan batik. Omzet pemasaran batik ke luar negeri terus menerus meningkat dan keuntungan usaha terus bertambah. Kunci keberhasilan produksi batik dalam memenuhi permintaan ekspor melalui peningkatan jaringan hubungan produksi.

\section{(2). Strategi Rasional Dalam Perdagangan.}

Pengusaha batik untuk mengirimkan barang dagangan ke buyer di luar negeri terkait dengan kebijakan negara setempat. Kebijakan ekonomi pemerintah Malaysia terbuka bagi produk batik buatan Indonesia, akan tetapi dalam realisasinya masuknya produk batik buatan Indonesia ke Malaysia sangat sulit. Kesulitan ini berhubungan dengan prosedur dan pemeriksaan dokumen ekspor terkesan mencari-cari kesalahan. Dalam situasi prosedur ekspor seperti itu maka tidak mengherankan kalau pengusaha batik Laweyan memutuskan untuk ekspor kain dan sarung batik menggunakan merk perusahaan dagang luar negeri. Cara itu memudahkan batik buatan Laweyan Surakarta mudah masuk ke negeri Malaysia. Tindakan tersebut dapat dimaknai pengambilan alih hak merk merupakan suatu tindakan rasionalitas pengusaha batik untuk ekspor. Pengusaha menggunakan strategi rasional dalam ekspor dalam rangka mencari keuntungan.

Pengusaha batik Laweyan Surakarta mempertahankan perdagangan domestik dengan cara membangun jaringan hubungan pedagang 
dengan sistem koordinator wilayah (korwil). Pengusaha batik membangun saluran distribusi batik tulis melalui beberapa pengusaha sebagai koordinator wilayah dagang di kotanya masingmasing. Aliran pasokan barang dagangan dan uang berdasar langganan tetap ngalap nyaur. Pengusaha memasok barang dagangan pada awal bulan dan pengusaha korwil membayar barang dagangan tersebut satu bulan kemudian.

Pengusaha batik membangun jaringan hubungan relasional dengan jaringan perdagangan dengan sistem korwil relatif lama. Landasan utama jaringan hubungan dagang dengan sistem korwil berdasarkan pengalaman hubungan dagang yang lama dan panjang. Hubungan dagang antara pengusaha dengan pengusaha korwil harus disiplin, jujur, berprestasi, saling percaya, timbal balik dan kerja sama tim. Pengusaha menciptakan standarisasi pengiriman barang dagangan, kualitas produk, harga per satuan produk dan keuntungan per satuan produk. Barang dagangan diusahakan bervariasi sesuai dengan permintaan pelanggan di wilayahnya masing-masing. Keuntungan yang diperoleh pedagang korwil adalah kesempatan memperoleh persediaan barang dagangan sesuai dengan pemintaannya secara teratur. Selain itu, pedagang korwil akan memperoleh potongan harga dan memperoleh informasi patokan harga barang dagangan. Keuntungan bagi pengusaha adalah mendapatkan informasi produk yang sesuai dengan permintaan konsumen masing-masing wilayah, memperoleh kepastian aliran barang dagang-an dan uang kontan yang teratur juga mengurangi risiko perdagangan serta promosi pemasaran. Kunci kesuksesan jaringan hubungan dagang korwil adalah masing-masing tingkatan lembaga ekonomi dari industri ke agen distributor dan pedagang pengecer saling menyesuaikan ritme bisnisnya masing-masing.

\section{Jaminan Sosial Ekonomi}

Pengusaha Mbok Mase di kampung batik Laweyan mengembangkan kelompok usaha induk-semang berdasarkan ikatan kekerabatan menurut garis keturunan laki-laki. Hubungan induk (orang tua) dan semang (anak) berdasarkan hubungan saling percaya, hubungan saling tolong-menolong dan hubungan kerja sama di bidang usaha perbatikan.

Keluarga besar berfungsi memberikan perlindungan sosial-ekonomi bagi para anggotanya dan menjamin para anggotanya untuk memperoleh pekerjaan dan pendapatan di bidang usaha perbatikan. Kelompok induk semang sebagai saluran kerja sama bisnis, seperti saling memberikan informasi pasar, saling pinjam meminjam barang dagangan, modal uang tunai dan saling pinjam-meminjam sarana transportasi serta saling memberi order pekerjaan.

Pengalaman pahit akibat kalah persaingan dengan industri batik printing di tahun 1980-an mendorong pengusaha batik semakin loyal pada kelompok usaha induk semang dan kooperatif dengan sesama pengusaha batik. Pengusaha batik semakin takut tampil beda pengusaha-pengusaha batik lain dalam kampung batik Laweyan. Hal itu memantapkan keyakinan bahwa Allah akan memberikan rejeki kepadamanusia sesuai dengan kebutuhan hidupnya. Allah lebih tahu kebutuhan yang sesuai dan tepat bagi seseorang dan kampung batik. Ketentraman seseorang ditentukan oleh rejeki yang tidak lebih dan yang tidak kurang dari pendapatan anggota-anggota lain dalam kelompok kerjanya. Jika ada pengusaha batik jatuh bangkrut akibat dari tindakannya yang neko-neko, dapat mengganggu ketentraman orang lain. Agar tidak neko-neko maka antar pengusaha batik mengembangkan kebersamaan, tolong-menolong dan kerja sama.

Prinsip kebersamaan membentuk jaringan hubungan produksi nempakke dan jaringan hubungan dagang nitip dan hubungan dagang ngalap nyaur. Setiap pelaku ekonomi diberi kesempatan untuk berpartisipasi di dalam proses produksi dan perdagangan. Jaringan hubungan produksi nempakke dan jaringan hubungan dagang nitip dan ngalap nyaur berfungsi sebagai perlindungan bagi setiap pelaku ekonomi untuk memperoleh pekerjaan dan pendapatan. 


\section{Penutup}

Sarekat Dagang Islam mengembangkan keterlekatan nilai-nilai budaya kedalam tindakan ekonomi pengusaha batik. Nilai-nilai budaya yang berorientasi pada egaliter, produktif, saling menghormati, kebersamaan, toleransi dan tolongmenolong. Nilai-nilai budaya tersebut sebagai pendorong dan pembimbing dalam perkembangan ekonomi lokal kampung batik Laweyan.

Etos kerja santri ulet, gigih dan tekun, usaha bersama berbasis keluarga besar dalam kelompokkelompok usaha bersama indung-semang, partisipasi dan kebersamaan dalam mengelola aktivitas ekonomi bersama dalam Forum Pengembangan Batik Laweyan, hubungan kerja kemanusiaan ngenger antara pengusaha dengan buruh batik, keterlekatan nilai budaya tepa slira dalam hubungan-hubungan produksi dan perdagangan batik, jaringan hubungan sosial ekonomi perbatikan berdasarkan hubungan saling percaya, saling menguntungkan dan kerjasama serta jaminan sosial bagi setiap anggota komunitas untuk memperoleh pekerjaan dan pendapatan. Keterlekatan nilai-nilai budaya dalam tindakan ekonomi pengusaha batik tersebut terbukti bersifat adaptif terhadap perubahan sosial dari zaman ke zaman. Proses budaya ekonomi kampung batik Laweyan cenderung bersifat demokratis.

Kehandalan demokrasi ekonomi lokal kampung batik Laweyan mengamanatkan perlunya keberpihakan pemerintahan pusat terhadap ekonomi lokal. Kebijakan ekonomi nasional diharapkan memprioritaskan dan bertumpu pada ekonomi lokal. Pembangunan demokratisasi ekonomi nasional harus berakar dari ekonomi lokal yang berlangsung dengan kearifan ilmu pengetahuan dan teknologi, nilai-nilai sosial budaya, inisiatif dan kreativitas, organisasi sosial ekonomi dan kemandirian lokal. Demokratisasi ekonomi nasional yang sesuai dengan cita-cita dan nilai-nilai luhur bangsa Indonesia.

\section{Daftar Pustaka}

Gelinas, Jaques B. 2003. Juggernaut Politics. Understanding Predatory Globalization. London \& New York: Zed Books.

Doellah, Santosa, H. 2002. Batik Pengaruh Zaman dan Lingkungan. Surakarta: Penerbit Danarhadi

Larson, George D.1990. Masa Menjelang Revolusi Kraton dan Kehidupan Politik di Surakarta 1912-1942. Yogyakarta: Gadjah Mada University Press.

Priyatmono, Alfa Fabela. 2004. Studi Kecenderungan Perubahan Morfologi Kawasan di Kampung Laweyan Surakarta. Yogyakarta: Program Pascasarjana Universitas Gadjah Mada.

Soedarmono.1987. Munculnya Kelompok Pengusaha Batik di Laweyan Pada Awal Abad XX. Yogyakarta: Fakultas Pasca Sarjana Universitas Gadjah Mada.

Soetrisno, Loekman. 1991. Peran Industri Kecil di Indonesia Sebagai Wahana Pembangunan Pedesaan: Perkembangan dan Masalahnya. Dalam Gembong Tjitrosoepomo (ed) Industri Pedesaan dan MasalahPerkembangannya. Yogyakarta: Adytia Media.

Wijaya, Mahendra. 2008. Ekonomi Komersial Ganda: Perkembangan Kompleksitas Jaringan Sosial Ekonomi Perbatikan Di Surakarta. Disertasi S3. Yogyakarta: Pascasarjana UGM 